\title{
SCOLYTOIDEA (COLEOPTERA) 5: NOTES ON NEOTROPICAL PLATYPODIDAE, MAINLY FROM CENTRAL AMERICA
}

\section{By HaNS ReIchaRdT*}

The present paper, fifth in a series of contributions towards the knowledge of Neotropical Platypodidae (see Reichardt, 1964b, for previous papers), deals mainly with the Platypodidae I was able to study in the Museum of Comparative Zoology, Cambridge, Mass. In this collection I recognized a new species from British Honduras, along with interesting new distributional records of some previously known species. The new data are summarized in a map (fig. 9), together with the records available in the literature. The result is a fairly good summary of the distribution of the genus Tesserocerus in Central America. It is discussed below, under that genus. Platypus pini Hopkins, previously known only from the type, is redescribed, figured, and assigned to another species group within the genus.

One specimen of Tesserocranulus nevermanni Schedl, interesting not only for the rareness of material of this genus but also for the locality, was kindly loaned for study by its collector, Dr. A. Prosen, Argentina, to whom I am greatly indebted. To Dr. O. L. Cartwright, United States National Museum, I am grateful for having made the type of Platypus pini available for study. Finally I am also indebted to Prof. P. J. Darlington, Jr., after whom I name the new species described below, for his assistance during my studies at Harvard University.

$$
\begin{aligned}
& \text { Genus Platypus Herbst, I } 793 . \\
& \text { "caudati”" group. } \\
& \text { Platypus pini Hopkins, 1905. }
\end{aligned}
$$

(figs. I-2).

Platypus pini Hopkins, 1905, Proc. Ent. Soc. Wash., 7:71. Holotype, ô, Chalco, Mexico, United States National Museum; examined.

Male: head with flat front, with big, areolate punctures; vertex with scattered normal punctures; covered with some long hairs. Antennae normal for the group. Prothorax with big, sparse punctures over its surface; median sulcus well marked in the posterior third; femoral grooves normally developed. Elytra punctate-striate, with all striae formed by a single row of punctures; base forming a sharp

\footnotetext{
* Departamento de Zoologia, Secretaria da Agricultura, Sao Paulo, Brazil; presently at Harvard University. Manuscript received by the editor January 22,1965
} 
carina, running from suture to fifth interstice; interstices normally convex; base of third slightly wider, with a few granules (3-4). Interstices alternate on the last third of elytra; first one ending at declivity, without formation of tooth or spine, but with some few granules; third with long spine at declivity; fifth and seventh with very much shorter spines, the fifth being the longest of the two; even interstices and ninth ending like the first, with a few granules at beginning of declivity. Lateral margin prolonged posteriorly to form the outer projection of the declivity; between this and the suture, another projection, triangular in shape. Abdomen normal.

Measurements: total length, $4.9 \mathrm{~mm}$.; maximum (elytral) width, r.54 mm.; elytral length, $3 \mathrm{~mm}$.; pronotal length, I. $3 \mathrm{~mm}$.; maximum pronotal width, $1.45 \mathrm{~mm}$.

Examined material: I $0^{\star}$, collected 7 miles north of San Cristobal Las Casas, Chiapas, Mexico (altitude: 2,100 m.; Km. I, I52 of Pan American Highway), 2. VIII. 1964, by J. Shetterly.

Hopkins did not assign his new species to any of the groups in which the genus was divided by Chapuis; Strohmeyer (1912, Coleopterorum Catalogus, Pars 44), lists P. pini as a member of the "trispinati" group, and to this group it has been referred since. The study of the type and the present specimen, however, showed that $P$. pini is a member of the "caudati" group. By the presence of two posterior projections on each elytron, this species is easily distinguished from all the other members of the group. Both localities where $P$. pini has been collected (Chalco, Mexico - misspelled Chaleo by Hopkins - and San Cristobal Las Casas, Chiapas) are situated at or above $2,100 \mathrm{~m}$., suggesting that the species may be restricted to higher altitudes.

\section{"costellati" group \\ Platypus pulchellus Chapuis, 1865.}

Platypus pulchellus Chapuis, 1865, Monogr. Platyp. :230, fig. 134. Holotype $\hat{o}$, San Juan Baptista (Villa Hermosa), Tabasco, Mexico; Blandford, 1896, Biol. Centr. Amer., Col., 4(6) :112. Allotype o, El Zapote, Guatemala.

This species is widespread over Central America, and one record is known from Venezuela (Schedl, I960b). It has already been recorded from several localities (summarized on fig. 9) in Mexico

Explanation of Plate 11

Fig. 1, Platypus pini Hopk., lateral view; fig. 2, P. pini Hopk., dorsal view ; fig. 3, P. darlingtoni, n. sp., lateral view ; fig. $4, P$. darlingtoni, n. sp., dorsal view; fig. $5, T$. nevermanni Schedl, lateral view; fig. $6, T$. nevermanni Schedl, dorsal view. 

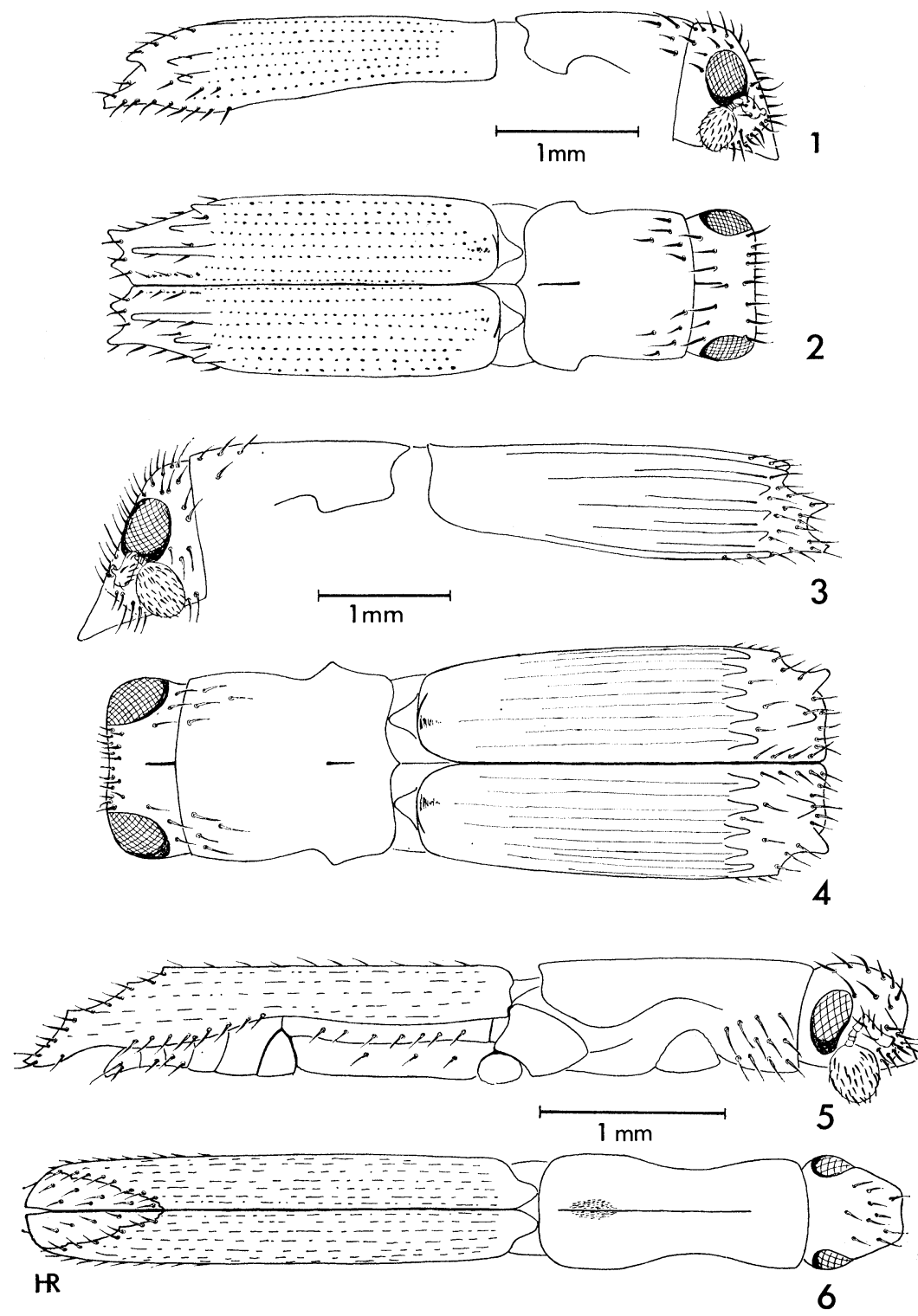

ReichardT - Platypodidae 
(Schedl, I940; 1956; 1963), Guatemala (Allotype), Costa Rica (Schedl, 1933).

New records from the Museum of Comparative Zoology collection are: I $0^{7}$, Toledo District, British Honduras, 20. IX. I906, Peck col.; $20^{\circ}$, I우, Lancetilla, Tela, Honduras, Stadelmann col.

\section{Platypus darlingtoni, n. sp.} (figs. 3-4).

Male: head with front slightly concave in the middle, densely rugose on all its surface; vertex as rugose as front; with few scattered hairs. Antennae of the typical form of the "costellati" group. Prothorax densely and finely punctured all over its surface; femoral grooves well developed; median sulcus well marked in the posterior third. Elytra: base raised to form sharp ridge, running from suture to fifth interstice; interstices carinate in the posterior third of elytra; sulci regularly and finely punctured from base to beginning of declivity; uneven interstices ending on the upper margin of the declivity in blunt spines, the first and third being the longest and best developed, subequal in length; the fifth, seventh and ninth less well developed, also subequal in length; the even interstices end on upper limit of the declivity, without formation of blunt spines; posterior margin of declivity with a well developed tooth on the latero-posterior angle; declivity rugose and setose, with an additional tooth between the third interstice and the posterior margin. Last abdominal sternite with two well developed teeth. Anterior tibiae with 5-7 transverse carinae.

Measurements: total length, $5.5 \mathrm{~mm}$; maximum width, $\mathrm{I} .75$ $\mathrm{mm}$.; elytral length, $3.2 \mathrm{~mm}$.; pronotal width, $\mathrm{I} .4 \mathrm{~mm}$.; pronotal length, $\mathrm{I} .5 \mathrm{~mm}$.

Holotype, I $O^{x}$, from Toledo District, British Honduras, 20. IX. 1906, Peck col., in the Museum of Comparative Zoology (M.C.Z. n. 3II47).

Platypus darlingtoni, n. sp., is the second species of the "costellati" group to be recorded from Central America. It is readily distinguished from the other species, mentioned before, which occurs at the same locality, by its larger size $(P$. pulchellus Chapuis is barely $3 \mathrm{~mm}$. long), and by its differently shaped and armed posterior declivity.

Genus Tesserocerus Saunders, I 836.

This genus has a typical Neotropical pattern of distribution, with its main dispersal center in South America. Of the 22 known species, 
only five occur in Central America (only two of them endemic). It appears that the limits of the genus in the Mexican NearcticNeotropical transition zone lie in the State of Vera Cruz on the Atlantic side, and in the State of Nayarit on the Pacific side. However, the records are not continuous on the Pacific side: none is yet known between the Tehuantepec Isthmus and Nayarit. Of the five Central American species, three are represented in the Museum of Comparative Zoology, as follows.

Tesserocerus belti Sharp, I880.

Tesserocerus belti Sharp, 1880, Ent. Monthl. Mag., 17:112. Types, $\hat{o}$ and \%, Chontales, Nicaragua.

Besides the type-locality, this species is known from several localities in Costa Rica (Schedl, I933; 194I) and Quito Ecuador (Schedl, I94I), as shown in fig. 9 .

New records from the Museum of Comparative Zoology collection are: I $\sigma^{7}$, Iㅇ, Esquinas, near Golfito, Dept. Puntarenas, Costa Rica, I948, P. \& D. Allen col.

\section{Tesserocerus ericeus Blandford, 1896.}

Tesserocerus ericeus Blandford, 1896, Biol. Centr. Amer., Col., 4(6):115-116.

Types, $\hat{\delta}$ and $+\hat{q}$, from several localities in Mexico, Guatemala and Panama

In describing the female of this species, Blandford points to the fact that it is almost indistinguishable from $T$. linearis Chapuis, a species described from a single female collected in Spain, and which Chapuis guessed had been imported from Brazil. In his revision of Chapuis' types of Platypodidae, Schedl (I960a) was unable to locate the type of linearis. Its real identity remains to be cleared. It may actually correspond to Blandford's species, since the locality given by Chapuis for linearis, Brazil, as said above, is based on pure guess.

$T$. ericeus is known only from Central America, from several localities in Mexico (Schedl, 1940), Guatemala (Blandford, I896), Costa Rica (Schedl, I933), and Panama (Blandford, r896), as summarized in fig. 9 .

New records from the Museum of Comparative Zoology collection are: I $0^{\lambda}$, Lancetilla, Tela, Honduras, Stadelmann col.; iq, Barro Colorado Island, Canal Zone, Panama, 1924.

Tesserocerus dewalquei Chapuis, I 865 .

Tesserocerus dewalquei Chapuis, 1865, Monogr. Platyp. :300, fig. 184. Types, $\hat{o}$ and + , Ega, Amazonas, Brazil.

Tesserocerus aubei Chapuis, 1865, 1.c.:301, fig. 185. Types, $\hat{o}$ and $q$, Santa Catarina, Brazil.

Tesserocerus dejeani Chapuis, 1865, 1.c.:303, fig. 187. Types, $\hat{\delta}$ and $q$, Colombia, Mexico. 

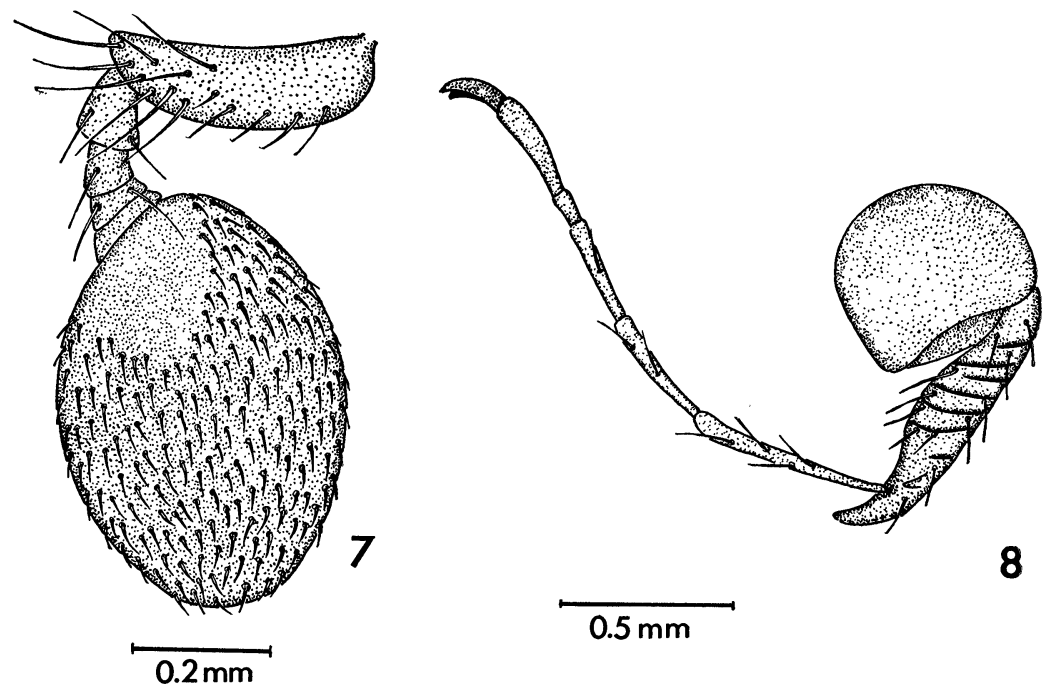

8

$0.5 \mathrm{~mm}$

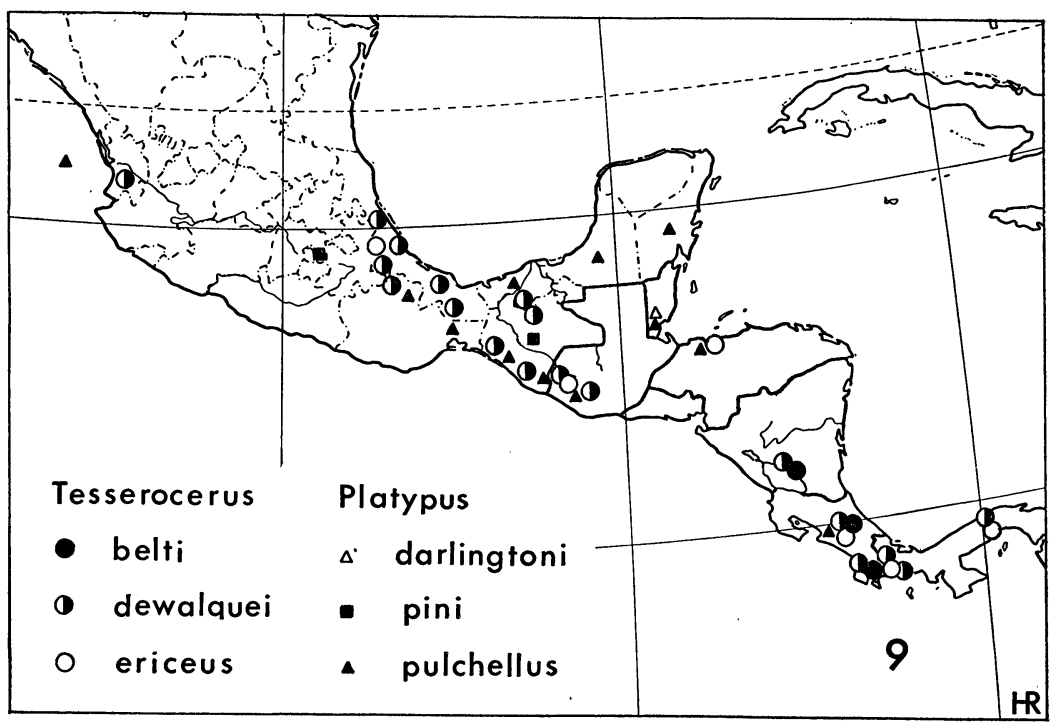

ReichardT - Platypodidae 
T. dewalquei is widely spread over South and Central America. Chapuis' $T$. dejeani has been recognized as a junior synonym of dewalquei by Schedl (I960a); the same author (1963), has subsequently used dejeani for Mexican specimens. Having seen specimens from South and Central America, I believe these species must be considered synonyms, as originally proposed by Schedl.

In Central America, T. dewalquei (recorded always as dejeani) is known from several localities in Mexico (Blandford, I896; Schedl, 1933; 1940; 1952; 1960a; 1963), Guatemala and Nicaragua (Blandford, I896), Costa Rica (Blandford, I896; Schedl, I933), and Panama (Blandford, I896); as shown in fig. 9.

New records from the Museum of Comparative Zoology collection are: $20^{\star}$, Barro Colorado Island, Canal Zone, Panama, 24. VII. 1924, W. M. Wheeler \& Nathan Banks col.; i $0^{\star}$, Esquinas, near Golfito, Dept. Puntarenas, Costa Rica, 1948, P. \& D. Allen col.

Genus Tesserocranulus Schedl, 1933.

Very little is known about this genus. Only very few specimens from wide apart localities have been studied; both sexes are known only in T. nevermanni, type of the genus. It seems, however, basically South American in distribution, with at least one of the three species ( $T$. nevermanni Schedl) reaching into Central America. T. Alexibilis Schedl, known only from females, was recently redescribed and illustrated (Reichardt, 1964a). Study of additional material, especially of males, may necessitate removal of this species from Tesserocranulus. The female, at least, has very peculiar antennal structure and head shape. T. ornatus Schedl, based on one female, from an unspecified locality in Brazil, is known only from the type.

\section{Tesserocranulus nevermanni Schedl, 1933.} (figs. 5-8).

Tesserocranulus nevermanni Schedl, 1933, Rev. Ent., 3 :164-165. Holotype $\hat{o}$, Hamburgfarm, Costa Rica; 1935, Ent. Nachrbl., 9:151. Allotype + , Cayenne.

Examined material: I $\sigma^{\star}$, Espejo, Santa Cruz, Bolivia, II. I962, A. F. Prosen col. (Prosen collection, n. 23440).

$T$. nevermanni, previously known only from the two original localities, is now recorded from Bolivia. This record extends the range of the species far to the south, and may indicate that never-

Explanation of Plate 12

Fig. 7, T. nevermanni Schedl, antenna; fig. 8, T. nevermanni Schedl, anterior leg; fig. 9, distribution of some species of Tesserocerus and Platypus in Central America. 
manni is distributed throughout the Amazonian Basin and adjacent areas. The original description seems detailed enough to permit identification of the species. I have not therefore prepared a new description of the available specimen, which is illustrated. The antenna (fig. 7), which is strikingly different from that of $T$. Alexibilis (see Reichardt, 1964a, fig. 5), shows an interesting small hairless patch on the club, around the funicle insertion point. This character has not yet been observed in any other genus of Platypodidae. It is also absent in $T$. flexibilis.

\section{REFERENCES}

BLANDFORD, W.

1896. Platypodidae, in Biologia Centr. Amer., Col., 4(6) : 97-144.

REICHARDT, H.

1964a. Scolytoidea (Coleoptera) 2: Sôbre Platypodidae neotropicais, com descricão de um alótipo. Pap. Avuls. Dep. Zool., 16: 145-151, 10 figs.

1964b. Scolytoidea (Coleoptera) 4: Notas sobre a sistemática e biologia de Platypodidae neotropicais. Rev. Bras. Ent., 11: 85-90, 12 figs. SchedL, K. E.

1933. New Platypodidae from Central and South America, Rev. Ent., 3 : 163-177.

1940. Fauna Mexicana, I. An. Esc. Nac. Cienc. Biol., 1:317-376, 3 pls.

1941. Platypodidae und Scolytidae. Rev. franc. d'Ent., 7: 152-157.

1952. Neotropical Scolytoidea. V. Pan-Pac. Ent., 28 : 122-124.

1956. Some bark- and ambrosia-beetles from the Tres Marias Island, Mexico. 1. c., 32: 30-32, 1 fig.

1960a. Chapuis Platypodidae: eine Revision mit Ergaenzungen. Mém. Inst. R. Sci. Nat. Belg., (Sér. 2) 62: 3-68, 1 fig.

1960b. Bark- and timber-beetles from the Neotropical region. Col. Bull., 14: 74-80.

1963. Fauna Mexicana, II. Ent. Arb. Mus. Frey, 14: 156-167. 

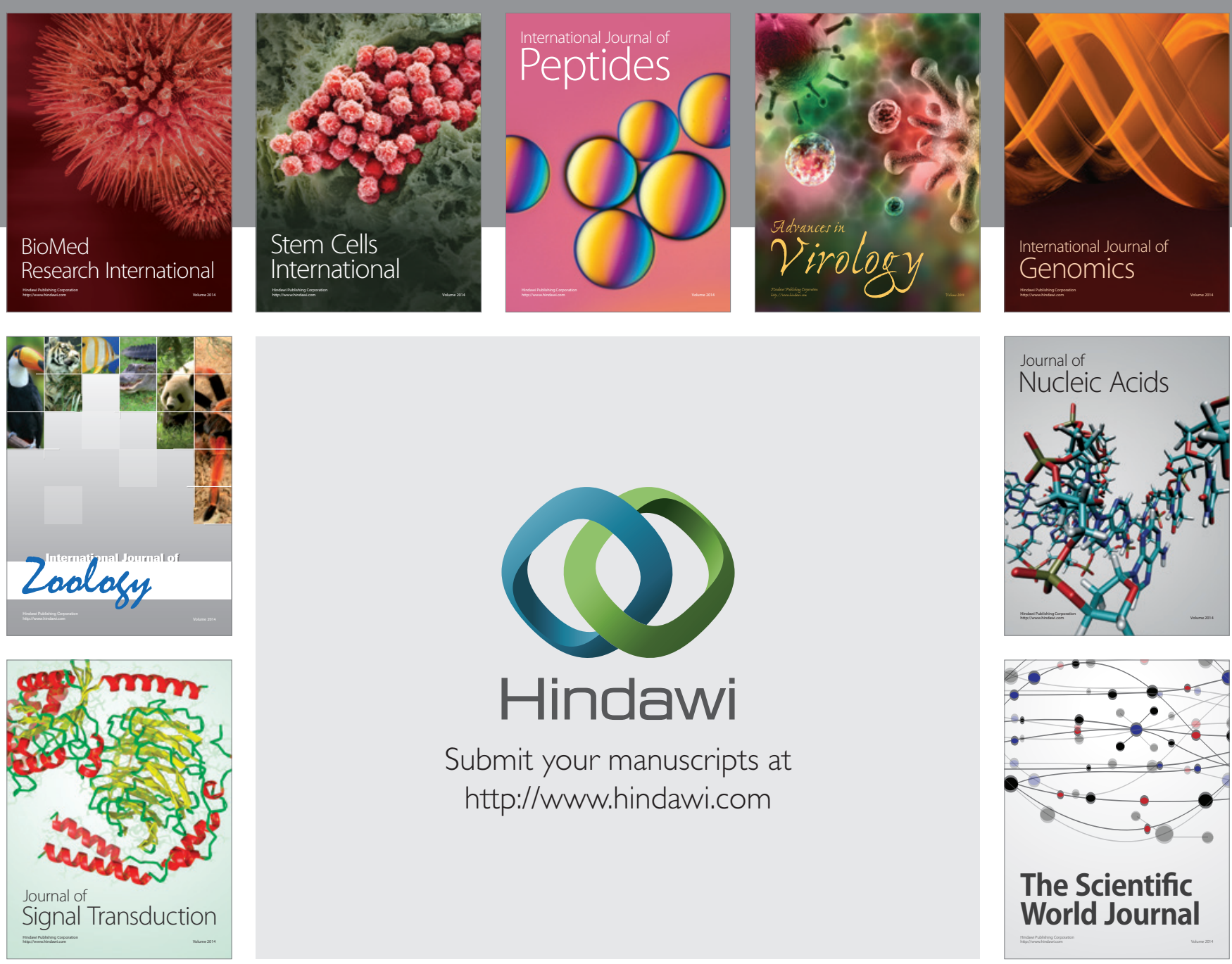

Submit your manuscripts at

http://www.hindawi.com
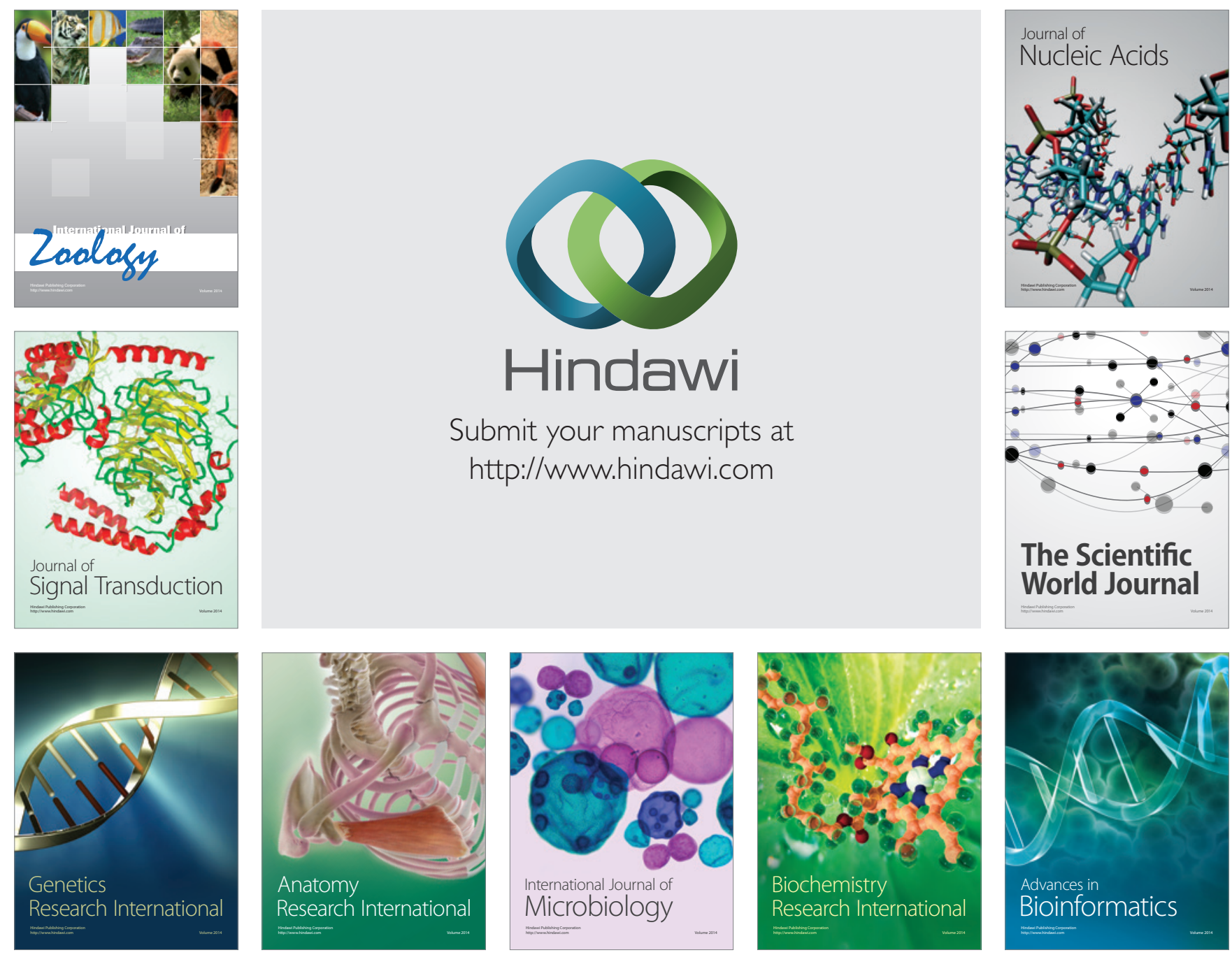

The Scientific World Journal
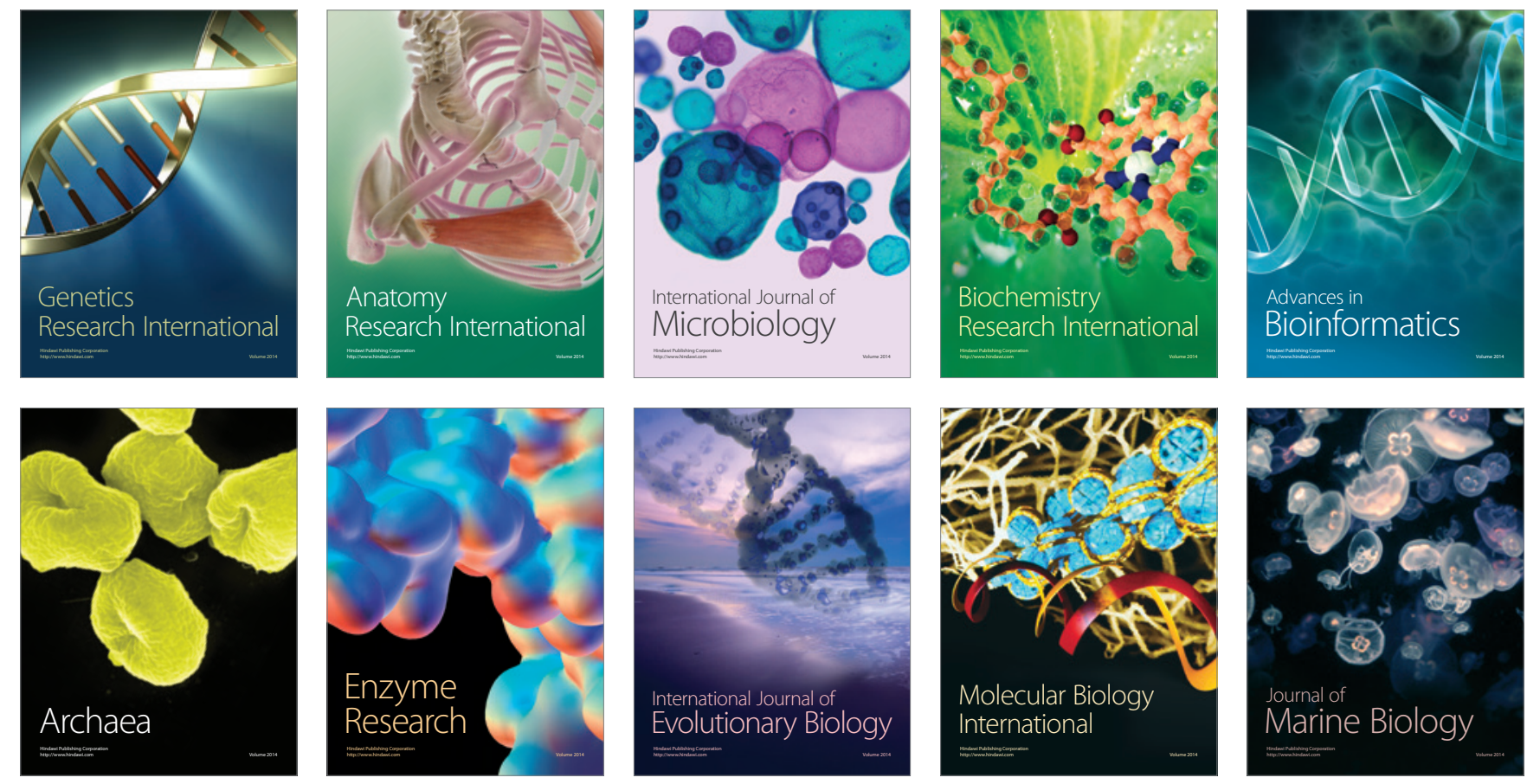